Vol. 5, n' 1 | 2001

Varia

\title{
Pearson, Edmund Lester. Studies in Murder
}

ed. by. Roger Lane. Columbus, Ohio : Ohio University Press, 1999.

Introduction, $\mathrm{x}-\mathrm{xvi}$; text, 295 pages

\section{Amy Gilman Srebnick}

\section{(2) OpenEdition \\ 1 Journals}

Electronic version

URL: https://journals.openedition.org/chs/797

DOI: $10.4000 /$ chs. 797

ISSN: 1663-4837

Publisher

Librairie Droz

\section{Printed version}

Date of publication: 1 January 2001

Number of pages: $145-146$

ISBN: 2-600-00607-9

ISSN: 1422-0857

\section{Electronic reference}

Amy Gilman Srebnick, "Pearson, Edmund Lester. Studies in Murder", Crime, Histoire \& Sociétés / Crime, History \& Societies [Online], Vol. 5, $n^{\circ} 1 \mid$ 2001, Online since 02 April 2009, connection on 22 March 2022. URL: http://journals.openedition.org/chs/797 ; DOl: https://doi.org/10.4000/chs.797 
Pearson, Edmund Lester. Studies in Murder, ed. by. Roger Lane. Columbus, Ohio : Ohio University Press, 1999. Introduction, x-xvi; text, 295 pages

These five tales of celebrated American crimes written by Edmund Lester Pearson, and first published in 1924, are short classics that only get better with time. Pearson, a Harvard educated New Englander and librarian by profession, was a master crime writer, probably one of the finest and certainly one of the most prolific. His tales of murderous events helped to define the genre of «true crime»; narrative accounts of criminal and usually sensational events that are based on trial records and contemporaneous chronicles. Indeed, for several generations Pearson's work was the way readers came to know the stories of many of America's most infamous crimes. Yet, for all of their historical authenticity, their dependence on trial records and newspaper accounts, his crime tales are as richly detailed as any fictional mysteries or detective novels, his «characters », drawn from life, are quirky and complicated, and his «resolutions » often leave room for questions and even doubt.

Studies in Murder has seen many editions, including a Modern Library edition in 1938. Ohio State University Press has reissued it in its original form accompanied by a short but beautifully written introduction by Roger Lane, the American social historian of crime and murder. Lane's introduction chronicles Pearson's professional and literary career and provides a bit of his literary biography : Pearson came to New York in 1924, became editor of publications for the New York Public Library, and eventually wrote full time contributing frequently to Vanity Fair and The New Yorker. More importantly, Lane's essay helps to frame Pearson himself as a late Victorian, a man who was fascinated by crime stories, not so much for their lurid or even romantic possibilities, as for the richness of the stories themselves and for the way they provide windows into small town American life, dysfunctional families, the power of the press and pubic opinion, and the workings of the American criminal justice system. And, as Lane also reminds us, Pearson's work reveals a man with a deeply ironic sense of humor, and a man who while remaining detached from his often horrific subject matter, was not reluctant to show his sympathy for the victims of crime or those (especially the poor) who were unfairly caught in the net of an often unjust legal system.

This collection contains the accounts of five very different murders: «The Borden Case» (1872), in which Lizzie Borden was accused (and acquitted) of the ax murder of her father and stepmother in their home in Fall River Massachusetts; «The Twenty-Third Street Murder» (1870), about the violent death of Benjamin Nathan, a wealthy New Yorker (possibly also a case of parricide); «Mate Bram !»(1896), the story of a triple murder at sea ; « The Hunting Knife» (1904), the tale of the murder of middle aged woman in her tidy home just west of Cambridge Massachusetts; and finally «Uncle Amos Has a Dream» (1812), the case of the presumed murder of Russel Colvin, a somewhat strange man known to disappear for long periods from his family home in Manchester, New Hampshire. All of these were cases of brutal murder, four of them stories of dysfunctional and probably murderous families, and all of them resulted in well-publicized trials.

It is the first case, the story of the ax murder of Lizzie Borden's father and stepmother, that is of course the most famous and Pearson gives it the most attention (he wrote more on it later in his career). This is not only because he believed it to be «without parallel in the criminal history of America», but because for Pearson it contained all of the essential elements «which make such an event worth reading 
about». It was, he tells us, a «mysterious crime in a class of society where», he believed, «deeds of violence are not only foreign, but usually wildly impossible» the upper or upper-middle classes. It was "purely a problem in murder», the evidence was "purely circumstantial", chance figured prominently in sequence of events, and finally, it was a case that attracted national attention. Thus, in his own introductory words, Pearson introduces us to his literary perspective on crime writing, a vocation he took quite seriously not only for its entertainment value - its storytelling possibilities - but also for the range of commentary such tales provoked about daily life and culture in the American past.

And for the historian this is precisely where Pearson's work is so interesting and rich. He always contextualized his crime narratives, providing beautifully drawn descriptions of a specific town or street, details of domestic interiors and family habits, and even brief accounts of pertinent national and international events. Thus the settings themselves take on a richness characteristic of Conan Doyle or Edgar Poe, while the historical context is both precise and time specific. In addition, Pearson's tales are always sensitive to the nuances of social class and position - the witnesses who must be jailed to be secured, the culinary details of a Victorian household - as well as to the legal and judicial issues involved in high profile murder cases. Equally interesting is his own fascination with the influence of the press on public opinion and the ways in which sensational events are refigured from their original tellings in the public press into a range of popular literary works - novels, stories and plays.

Pearson deserves more significant study (I was unable to turn up one recent critical treatment of him). He wrote a great deal and his work, both the occasional essay, the commentaries on books and book collecting, and certainly his crime stories, offer much to the general reader as well as to the literary scholar and historian of crime and culture. I hope that the publication of Studies in Murder indicates a renewed interest in Pearson's work.

Amy Gilman Srebnick

Montclair State University

Srebnicka@mail.montclair.edu

\section{Levene (Mark) and Roberts (Penny), (Eds.), The Massacre in History, Oxford, Berghahn Books, 1999, 320 pp., 6 half-tones, maps, ISBN 1571819347}

Massacres are everywhere. At least that is the impression one could get from recent newspaper headlines like: «Massacre at Columbine High School». «Jaguars massacre Dolphins». «Massacre in Yugoslavia». From a shooting by some disgruntled teenagers to sports, like the devastating defeat meted out to the Miami Dolphins by the Jacksonville Jaguars, to the annihilation of a village in the Balkans, massacres seem to be all around us. A search of the word «massacre» on the Internet produces at a minimum over 250000 sites. And therein lay the problem. The concept of massacre has become so ubiquitous in common and scholarly discourse that it has lost much of its analytical utility. The publication of a collection of scholarly essays devoted to the massacre in history should, therefore, be most welcome. Unfortunately, the essays in this volume only muddy the already murky waters about «massacres». While laudably broad in geographical scope, encompassing 